\title{
Protective effect of ginseng against toxic effect of ochratoxin (OA) in kidney of male rats
}

\author{
Fatma A. Morsy \\ Basic Meidcal Sciences Department, Pathology Researches, National \\ Research Center
}

\begin{abstract}
A total of 62 male albino rats were used in this study 8 rats were used as control. The remaining were divided into 9 groups. Three groups were injected with ochratoxin (OA) at dose level of $0.85 \mathrm{mg} / \mathrm{kg}\left({ }^{1} /{ }_{10} \mathrm{LD} 50\right)$ for 2,4 and 8 weeks respectively. Three other groups were treated with ginseng $(20 \mathrm{mg} / \mathrm{kg}) 10 \mathrm{~min}$ before OA injection following the same previous schedule of injections. The remaining groups were injected with ginseng only. Paraffin sections were used for histopathological study. For histochemical investigations, sections were stained to demonstrate the glycogen, DNA, protein and alkaline phosphatase activity. OA showed sever histopathological effects on kidney demonstrated as pyknosis in some tubules and vacuolar degeneration in tubular epithelial cells. Also cell debris and hyalin casts were present in lumen of tubules. The histochemical results showed a decrease in DNA, protein content and negative reaction for glycogen and alkaline phsophatase activity. The ginseng was found to reduce the deleterious effect of OA.
\end{abstract}

\section{Introduction}

Ochratoxin A (OA) is a naturally occurring mycotoxin produced by a spergillus ochraceus as well as other moulds found on a variety of food stuffs in many countries (Baudrimant et al., 2001). It is a nephrotoxic, hepatotoxic, teratogenic, carcinogenic, to animals and possibly to humans (Dorrenhaus et al., 2000 and Zanic- Grubisic et al., 2000) and immunosuppressive (Bondy and Pestak 2000).

It is a common feed contaminant, which may impair animals health and may lead to residues in edible tissues of slaughter animals (Biro et al., 2002), it is wide spread contaminant in human staple food (Dorrenhaus et al., 2000). It has the ability to induce chromosomal aberrations in human peripheral lymph ocytes (Monalova et al., 1991). Another toxic effect is depletion of lymphoid cells in some mammals and poultry (Szczech et al.,
1973). The toxicity of OA may be due to :(1) inhibition of ATP production (2) inhibition of protein synthesis (3) promotion of membrane lipid peroxide ation (Marquadt and Frohlich 1992). Ochratoxin produces growth depression in body and organs weight in chicks (Kozaczynskiw, 1994 and Sandhu et al., 1995).

The ubiquitous mycotoxin ochrat oxin A (OTA) is associated with the development of urothelial tumors and nephropatheis in laboratory animals and in human (Brien et al., 2001).

Ginseng is a potent antioxidant and protects tissues from damage (Tran et al., 2002). Ginseng can inhibits lipid peroxidation of rabbit kidney (Zhang, 1992), reduces pulmonary edema which follows free radical injury (Kim et al., 1992), and inhibit cancer cell growth (Duda et al., 1999 and Nishino et al., 
2001). It reduces chromosomal aberra tions induced by irradiation and some chemicals (Kim et al., 1992 and Kim et al.,1999). It has the ability to stimulate ribonucleic acid and protein synthesis. This is considered as the basis of improvement of renal function (Zhang, 1992). Ginseng elevates the activity of enzymatic free radicals scavenger in cells (Lee et al., 2002).

The present work is conducted to investigate the possible histopatho logical and histochemical effects of ochratoxin and the protective effect of ginseng root against OA toxicity in kidney.

\section{Materials And Methods}

\section{Ochratoxin A :}

Crude OA was prepared and quantitatively determined by the method of Golinski and chelkowski (1978). $\mathrm{LD}_{50}$ of the toxin $(0.85 \mathrm{mg} / \mathrm{kg})$ in the rats was calculated using Karbr's method (Karbr, 1941).

\section{Experimental design :}

62 male albino rats weighting 150 $-170 \mathrm{~g}$ were included in this study. 8 rats were used as control and received $\mathrm{NaHCO}_{3}(1 \mathrm{~m} / \mathrm{kg})$. The remaining were divided into 9 groups. The first group was injected intraperitonealy daily with ochratoxin at a dose of $0.85 \mathrm{mg} / \mathrm{kg}(1 / 10$ $\left.\mathrm{LD}_{50}\right)$ of $\mathrm{OA}$ dissolved in $\left(\mathrm{NaHCO}_{3}\right)$, for 2 weeks. The second group was injected daily with OA for 4 weeks and the third group was injected with $\mathrm{OA}$ for 8 weeks at dose level of $0.85 \mathrm{mg} / \mathrm{kg}$ . The fourth, fifth and sixth groups were given ginseng $(20 \mathrm{mg} / \mathrm{kg})$ intraperi tonealy, 10 minutes before OA injection at daily dose of $0.85 \mathrm{mg} / \mathrm{kg}$ for 2,4 and 8 weeks respectively. The remaining groups were injected with ginseng following the same previous schedule of injection. Powder of ginseng root (aqueous extract ) was obtained from
IPECO company , $10^{\text {th }}$ Ramadan city, Egypt.

Histological and histochemical studies

The kidney of different groups were removed and fixed in $10 \%$ saline formol, $5 \mu \mathrm{m}$ thick paraffin sections were stained with haematoxylin and eosin (Durury and Wallington, 1980) and investigated by light microscope.

Sections of kidney were stained for DNA (Feulgen and Rosenbeck, 1942), mucopolysaccharides (MacManus and Cason, 1950), Protein (Mazia et al., 1953), Gomori stain (Gomori, 1951) was used for detection of alkaline phosphates activity and subjected to cytophotometric measure ment. Thirty readings representing samples of each group were secured. Significance of the results was evalua ted by using the student t-test (Snedcor and Cochran 1980).

\section{Results}

\section{Histopathological results of the kidney:}

The normal histological structure of the kidney was observed in. Fig. (1)

The kidney of the first group of animals treated with OA for two weeks showed tubular degeneration and cell debris in the lumen of tubules. Haemorrhagic area appeared in the interstitium and glomerular degene ration and highly degenerated tubular cells. (Fig.2)

The second group of rats treated with OA for four weeks showed vacuolar degeneration and focal necrosis in tubular epithelial cells. Mononuclear cellular infiltration and haemorrhage in the interstitial tissue. Moreover cell debris was noticed in the lumen of tubules. (Fig.3)

The third group of rats treated with OA for eight weeks, showed hyalin casts and cell debris in the lumen of tubules, vacuolar degeneration, focal 
area of necrosis and karyolysis in tubular epithelial cells, glomerular degeneration and prominent internal hemorrhage. (Figs.4,5)

The treatment of rats with ginseng and ochratoxin in combination for two weeks (fourth group), showed that tubular and glomerular degeneration was diminished. Haemorrhagic areas still present in the interstitium. (Fig.6)

The fifth and sixth groups of rats treated with $\mathrm{OA}$ and ginseng for four and eight weeks, showed interstitial and interglomerular haemorrhage, some protective effects appeared in compa rison with group of rats treated with OA only, in the form of diminution of hyalin casts and vacuolar degeneration. (Fig.7)

\section{Histochemical results of the kidney:}

Fig. (8) shows the normal distribution of DNA in the kidney of control rat.

DNA content in kidney cells of the rats injected with OA (Table 1, Fig.17) decreased significantly $(\mathrm{P} \leq$ 0.01 ) to $22.22 \%, 34.21 \%$ and $40 \%$ after two, four and eight weeks respectively. (Figs.9A,B,C)

Highly significant increase in DNA content $(\mathrm{P} \leq 0.01)$ was recorded in the case of rats treated with ginseng 10 min before ochratoxin injection especially after eight weeks by 122.85 (Fig.10C) relative to control value.

In normal rat high protein inclusions in renal tubular cells were localized in the cytoplasm and lesser extent in their nuclei. (Fig.11)

Also the optical density value of protein content (Table 1, Fig.17) of the previous group was significantly decreased when compared with control after two, four and eight weeks ( $\mathrm{P} \leq$ $0.01)$. The percentage of decrease of protein content was $11.90 \%, 23.25 \%$ and $47.61 \%$ at the three time intervals. (Figs. 12 A,B,C)

A significant increase in protein content $(\mathrm{P} \leq 0.01)$ was recorded in the case of rats given ginseng in combination with ochratoxin by $26.19 \%, 69.76 \%, 133.33 \%$ at different time of injections. (Figs 13 A, B, C)

The periodic acid schiff's (PAS) technique was used to demonstrate the presence of polysaccharides in the kidney. The PAS +ve materials were mainly distributed at the brush border and basement membrane of the tubules (Fig. 14).

Moreover, the glycogen content (Figs. 15 A, B, C) decreased significantly in kidney cells of the ochratoxin groups after two, four and eight weeks $(\mathrm{P} \leq 0.01)$ by $12.5 \%$, $15.38 \%$, and $37.5 \%$ respectively.

The injection of the rats with ginseng and ochratoxin led to significant increase in glycogen content after two, four and eight weeks respectively (Fig. 16 A, B, C) . (Table 1, Fig. 17)

In the control rat high alkaline phosphatase activity was observed in the lining cells of the tubules mainly at their brush border.

Alkaline phosphatase activity in kidney cells (Table 1, Fig.17) of the rats given $\mathrm{OA}$ increased significantly $(\mathrm{P} \leq$ 0.01 ) to $136.66 \%$ after eight weeks.

Also, the optical density value of alkaline phosphatase activity was significantly higher in the group of rat treated with ginseng and ochratoxin than that of control especially after eight weeks $(\mathrm{P} \leq 0.01)$ by $103.33 \%$.

The injection of the rats with ginseng only led to significant elevation of DNA, protein content and glycogen in kidney cells after two, four and eight weeks. The alkaline phosphatase activity increased significantly due to 
ginseng treatment after four and eight weeks.

\section{Discussion}

Ochratoxin A was found to be extremely toxic on kidney. The histo pathological and histochemical changes were all doses dependent. This in general is in agreement with the results of (Huff et al., 1974 and Prior, 1976).

The effect of ochratoxin on rat kidney were pronounced at different durations (Two, four and eight weeks). The drastic effect was dose dependent.

In the present work ochratoxin induced vacuolar degeneration and hyalin casts in kidney of rat after eight weeks, in contrary with Rasonyi et al., (1999). They noticed necrotic cells and cell exfoliations in rat kidney treated with ochratoxin. No hyalin casts were noticed.

In recent studies on ochratoxin, Biro et al., (2002), Pfohl-Leszkowicz et al., (2002), and Stoev et al., (2002). They found that the OA caused tubular degeneration, focal tubular epithelial cells proliferation, glomerulonephrosis, tubulo nephrosis in kidney of chiken.

The pathological changes obser ved in kidney of rats due to ochratoxin injection in the present work may be attributed to increase lipid peroxidation level and glutathione depletion (Meki and Hussein 2001, Baudrimont et al., 2001). Lipid peroxidation was stimulated by ochratoxin (Abdel Wahab et al., 1999).

Ginseng showed noticeable improvement in tissues treated with Ochratoxin. Nishino et al., (2001) and Tran et al., (2002). They reported that ginseng can increase body resistance to many harmful factors and protect tissue from damage and could inhibit lipid peroxidation of rat liver and kidney. Lee et al., (2002), stated that ginseng may reduce cell damage induced by toxic substance and acts to stabilize cell membranes there by providing protection against toxic agents induced tissue injury.

Free radicals were produced by mycotoxin (Petkova et al., 1998). The free radical attack DNA and lead to cross linkages within the molecules (Baudrimant et al., 2001).

In the present work ochratoxin A caused sever depletion in DNA content in kidney cells. This is in agreement with Bashandy et al., (1996) they found that ochratoxin A caused sever depletion in DNA content in spermatogenic cells. According to Wang and Groopman (1999) they recroded that mycotoxin produced chromosomal aberration, micronuclei, sister chromatid exchange and unscheduled DNA synthesis. Arlt et al., (2001), Lebrun and Fultmann (2002) Stated that ochratoxin induced DNA single strand breaks (SSB) and DNA adducts.

In the present work the injection of rats with ginseng and ochratoxin in combination, led to increase in DNA content in comparison with group of rats treated with ochratoxin only. This results is in agreement with (Bashandy et al., 1996) they recorded that the injection of rat with ginseng and ochratoxin led to increase in DNA content in spermatogenic cells.

The injection of rats with ginseng only, led to a significant increase in DNA content in kidney cells. These effects may be due to the antioxidant nature of ginseng (Nishino et al., 2001).

In the present work ochratoxin decreased the protein content in kidney cells after two, four and eight weeks. Schwerdt et al., (1999) stated that ochratoxin is known to inhibit protein synthesis. Increase in protein content was noticed after treatment with ginseng and $\mathrm{OA}$ at different durations in 
comparison with OA alone. Zhang (1992) reported that the treatment of ginseng caused increase amount of ribosome in rough endoplasmic reticulum in cells, reflecting their ability to protein synthesis.

In the present experiment ochra toxin A caused significant decrease in glycogen content in kidney cells after two, four and eight weeks. This result is in agreement with Kozaczynskiw (1994) who stated that no glycogen content was detected in kidney treated with ochratoxin. Theron et al., (1966) stated that the treatment of rats with OA showed periodic acid schiff staining of liver demonstrating evidence of mitochondrial damage. This is in disagreement with (Dwived and Burns, 1984). They noticed enzymatic inhibition of glycogenolysis in ochrato xin toxicosis and this could be due to excess glycogen observed in the kidney of rat. According to Sandhu et al., (1995), they found that the treatment of chicks with OA led to increase in mucopolysaccharides (MPS) in liver and kidney tissues. Increase in glycogen content was noticed after treatment with ginseng and $\mathrm{OA}$ at different durations in comparison with OA a lone. This is in agreement with Zhang (1992) who stated that ginseng had a protective effect on mitochondria, they appeared less damaged.

In the present work, increased reaction for alkaline phosphatase activity was observed after four and eight weeks. This is in disagreement with Kozaczynskiw (1994) who noticed a decrease in alkaline phsophatase activity in the brush border of renal tubules of male chickens treated with ochatoxin. According to Theron et al, (1996), noticed no change in alkaline phosphates activity due to ochratoxin.

\section{Conclusion :}

The occurrence of ochratoxin $\mathrm{A}$ in food and feed commodities causes many hazards to human beings and animals. It seems that kidney is a target organ of the ochratoxin, since the toxin affects the histology and histochemistry of kidney. This may be due to it's accumulation in the tissues (Bohm 1992) which represents a possible source of danger to man. On the other hand, ginseng reduces many harmful effects of ochratoxin in kidney

Table (1) : Effect of ochratoxin A (OA) $(0.85 \mathrm{mg} / \mathrm{kg} \mathrm{b.w})$ and or ginseng $(20 \mathrm{mg} / \mathrm{kg}$ b.wt) on DNA (ng/g), protein (ng/g), glycogen $(\mu \mathrm{g} / \mathrm{g})$ contents and alkaline phosphatase activity $(\mu \mathrm{g} / \mathrm{g})$ in kidney cells of male rats after two, four and eight weeks of intaperitoneal treatments.

\begin{tabular}{|c|c|c|c|c|c|c|c|c|c|c|c|c|}
\hline \multirow{2}{*}{$\begin{array}{l}\text { Time } \\
\\
\text { week } \\
\begin{array}{l}\text { Group } \\
\text { Parameters }\end{array}\end{array}$} & \multicolumn{4}{|c|}{$2 w$} & \multicolumn{4}{|c|}{$4 w$} & \multicolumn{4}{|c|}{$8 \mathrm{~W}$} \\
\hline & Control & $\mathrm{OA}$ & $\begin{array}{l}\text { OA+ } \\
\text { Ginseng }\end{array}$ & Ginseng & Control & $\mathrm{OA}$ & $\begin{array}{l}\text { OA+ } \\
\text { Ginseng }\end{array}$ & Ginseng & Control & $\mathrm{OA}$ & $\begin{array}{l}\mathrm{OA}+ \\
\text { Ginseng }\end{array}$ & Ginseng \\
\hline DNA & $\begin{array}{ll}* & \\
0.36 & \pm \\
0.01 & \end{array}$ & $\begin{array}{l}* \\
0.28 \\
0.02\end{array}$ & $\begin{array}{l}0.32 \pm \\
0.02\end{array}$ & $\begin{array}{ll}* * & \\
0.57 \quad \pm \\
0.01\end{array}$ & $\begin{array}{l}0.38 \\
0.01\end{array}$ & $\begin{array}{l}* * \\
0.25 \\
0.01\end{array}$ & $\begin{array}{l}0.42 \\
0.04\end{array}$ & $\begin{array}{ll}* * & \\
0.64 \quad \pm \\
0.01\end{array}$ & $\begin{array}{l}0.35 \\
0.01\end{array}$ & $\begin{array}{ll}* * & \\
0.21 & \pm \\
0.02 & \end{array}$ & $\begin{array}{ll}* * & \\
0.78 \quad \pm \\
0.02\end{array}$ & $\begin{array}{l}* \\
0.70 \quad \pm \\
0.01\end{array}$ \\
\hline Protein & $\begin{array}{l}0.42 \quad \pm \\
0.02\end{array}$ & $\begin{array}{l}0.37 \\
0.02\end{array}$ & $\begin{array}{l}* \\
0.53 \quad \pm \\
0.01\end{array}$ & $\begin{array}{ll}* * * & \\
0.67 \quad \pm \\
0.01\end{array}$ & $\begin{array}{l}0.43 \quad \pm \\
0.01\end{array}$ & $\begin{array}{l}* \\
0.33 \\
0.01\end{array}$ & $\begin{array}{ll}* * * & \\
0.73 & \pm \\
0.02\end{array}$ & $\begin{array}{l}\text { *** } \\
0.82 \quad \pm \\
0.03\end{array}$ & $\begin{array}{l}0.42 \quad \pm \\
0.1\end{array}$ & $\begin{array}{l}* * \\
0.22 \\
0.02\end{array}$ & $\begin{array}{ll}* * & \\
0.98 \quad \pm \\
0.01\end{array}$ & $\begin{array}{ll}* * * & \\
0.88 \quad \pm \\
0.01\end{array}$ \\
\hline Glycogen & $\begin{array}{l}0.40 \\
0.01\end{array}$ & $\begin{array}{l}* \\
0.35 \\
0.01\end{array}$ & $\begin{array}{l}* * \\
0.55 \quad \pm \\
0.01\end{array}$ & $\begin{array}{l}0.40 \\
0.01\end{array}$ & $\begin{array}{l}* \\
0.39 \quad \pm \\
0.001\end{array}$ & $\begin{array}{l}* \\
0.33 \\
0.01\end{array}$ & $\begin{array}{l}* * \\
0.56 \quad \pm \\
0.01\end{array}$ & $\begin{array}{l}* \\
0.48 \quad \pm \\
0.003\end{array}$ & $\begin{array}{l}0.40 \pm \\
0.01\end{array}$ & $\begin{array}{l}* * \\
0.25 \\
0.02\end{array}$ & $\begin{array}{ll}* * & \\
0.57 \quad \pm \\
0.01\end{array}$ & $\begin{array}{l}* * \\
0.86 \quad \pm \\
0.01\end{array}$ \\
\hline $\begin{array}{c}\text { Alkaline } \\
\text { phosphatase }\end{array}$ & $\begin{array}{l}0.29 \pm \\
0.03\end{array}$ & $\begin{array}{l}0.31 \\
0.01\end{array}=$ & $\begin{array}{l}0.28 \\
0.003\end{array}$ & $\begin{array}{l}0.33 \\
0.01\end{array}$ & $\begin{array}{l}0.30 \\
0.01\end{array}$ & $\begin{array}{l}* \\
0.40 \\
0.003\end{array}$ & $\begin{array}{l}* \\
0.38 \\
0.020\end{array}$ & $\begin{array}{l}* * \\
0.42 \pm \\
0.04\end{array}$ & $\begin{array}{l}0.30 \quad \pm \\
0.01\end{array}$ & $\begin{array}{l}* * \\
0.71 \\
0.020\end{array}$ & $\begin{array}{l}* * \\
0.79 \quad \pm \\
0.001\end{array}$ & $\begin{array}{l}* * \\
0.61 \quad \pm \\
0.02\end{array}$ \\
\hline
\end{tabular}

$*$, ** Significant difference from control $(\mathrm{P} \leq 0.01)$. 
Protective effect of ginseng against toxic.....

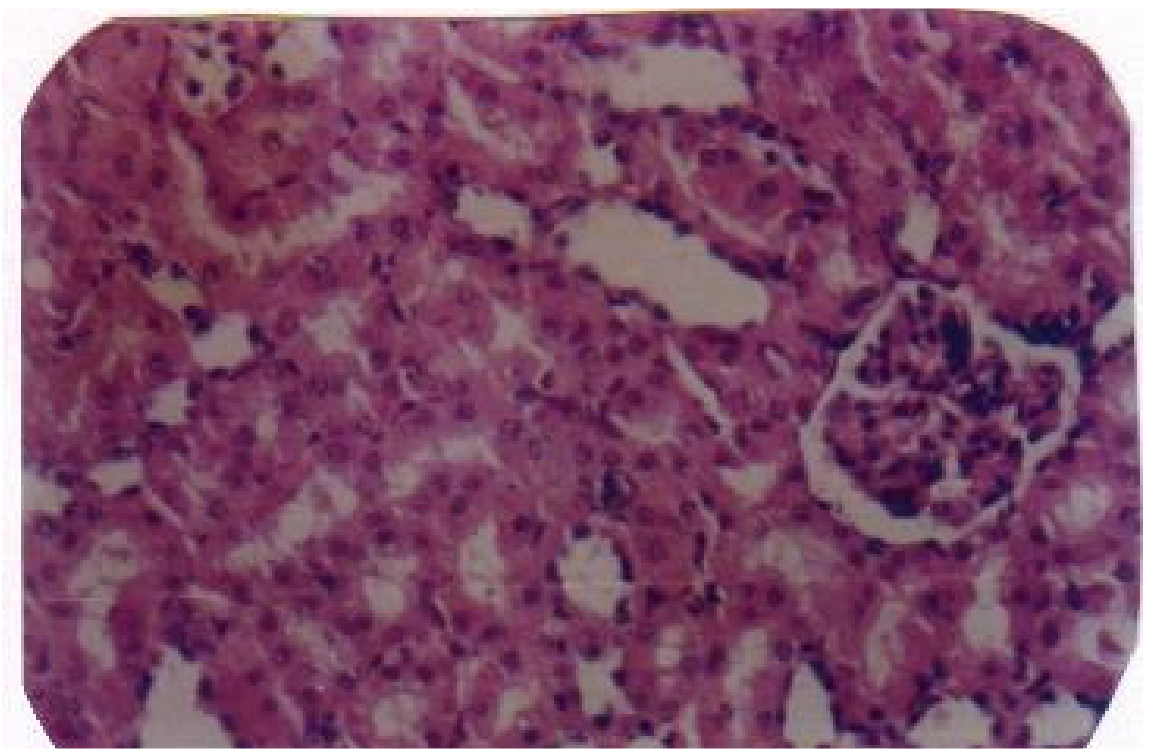

Fig (1): Section of the kidney of control rat showing normal appearance of glomerulus and renal tubules.

(Hx \&Ex 200).

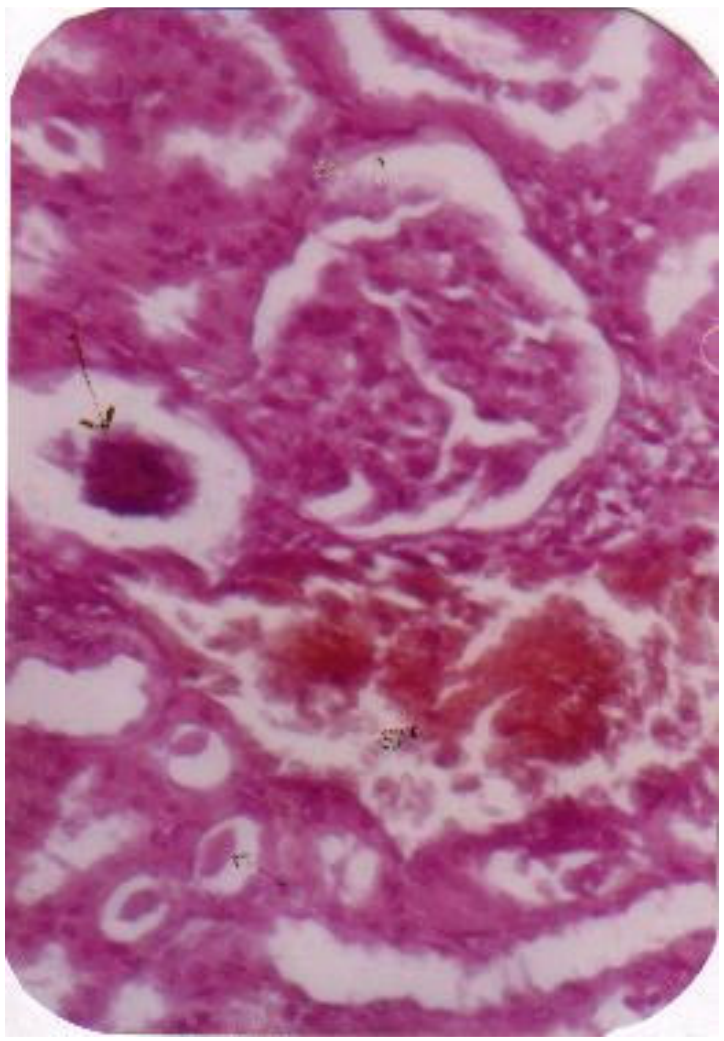

Fig (2): Section of the kidney of rat treated with ochratoxin for two weeks showing cell debris in the lumen of tubules (1), glomerular degeneration (2) and degenerated tubular cells. Haemorrhagic area in the interstitium (3).

(Hx \& Ex 200).

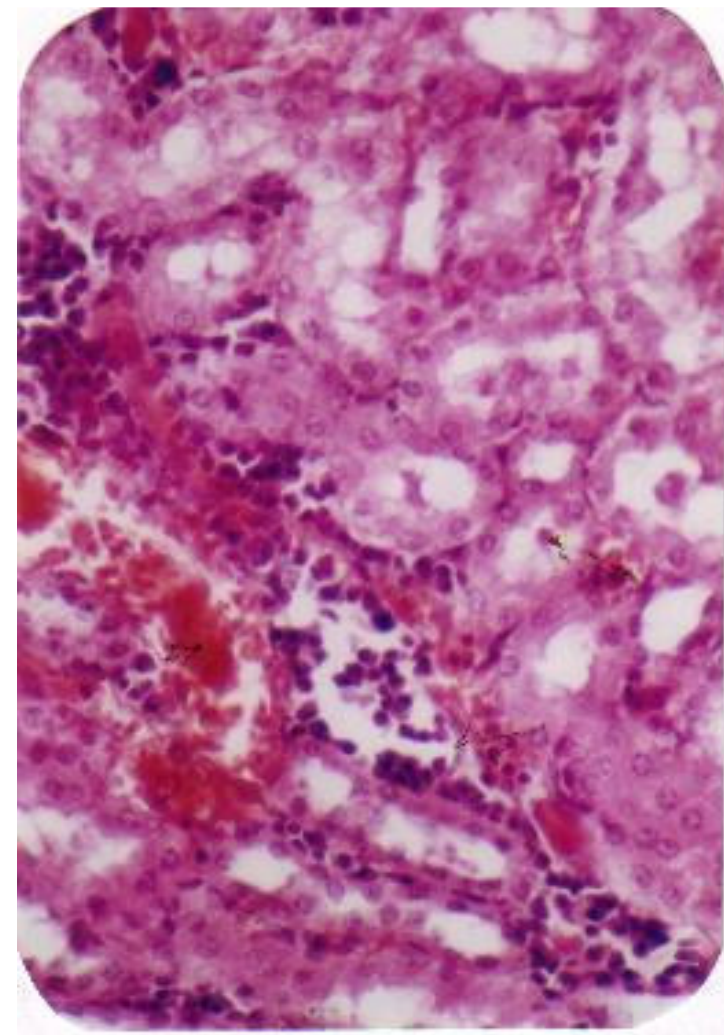

Fig. (3): Section of the kidney of rat treated with ochratoxin for four weeks showing mononuclear cellular infiltration (1) and haemorrhage in the interstitium (2). Cell debris in the lumen of tubules (3)

(Hx \& Ex 200). 


\section{Fatma A. Morsy}

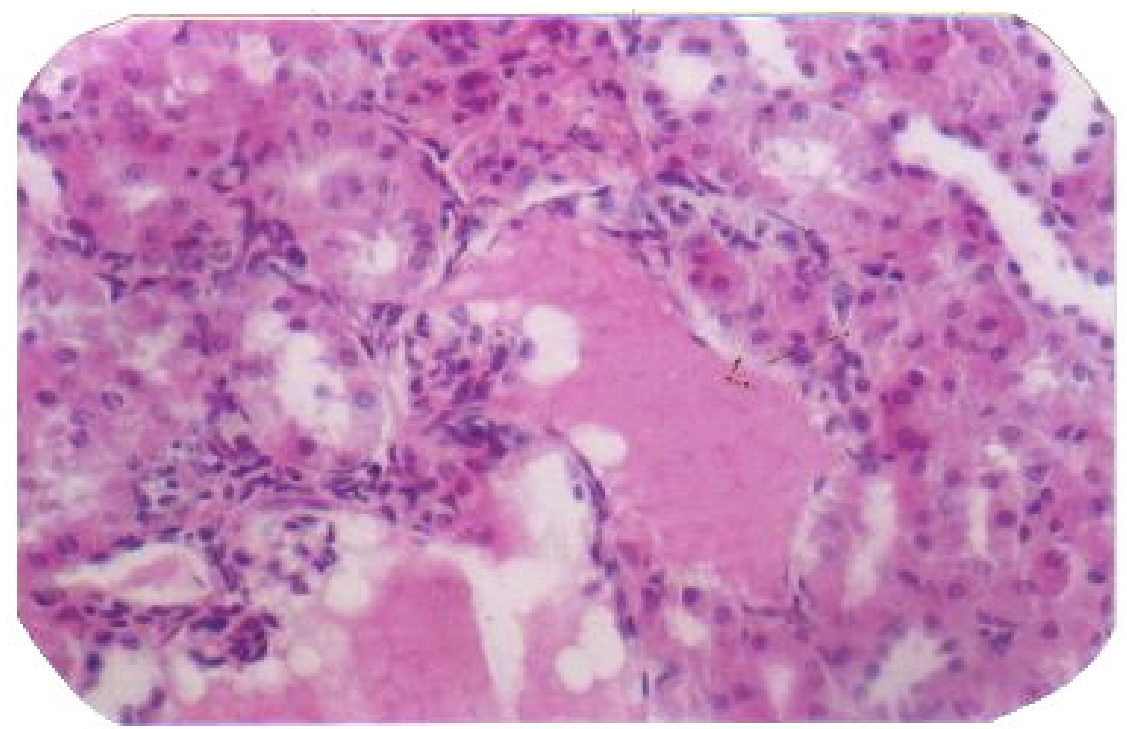

Fig. (4): Section of the kidney of rat treated with ochratoxin for eight weeks showing hyalin casts (1).

(Hx \& Ex 200)

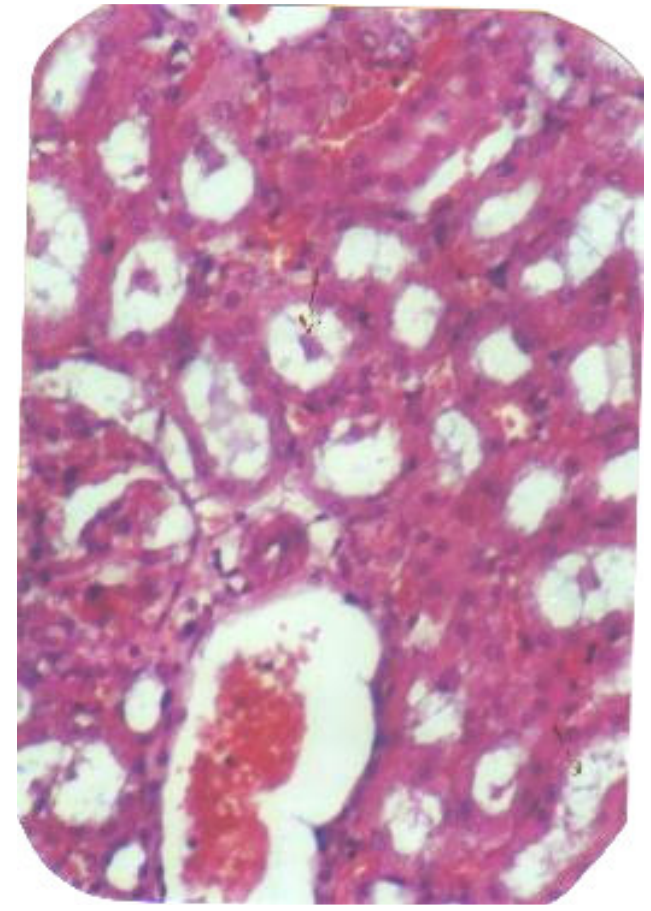

Fig. (5): Section of the kidney of rat treated with ochratoxin for eight weeks showing vacuolar degeneration (1). Cell debris in lumen of tubules (2) and prominent internal hemorrhage.

(Hx \& Ex200)

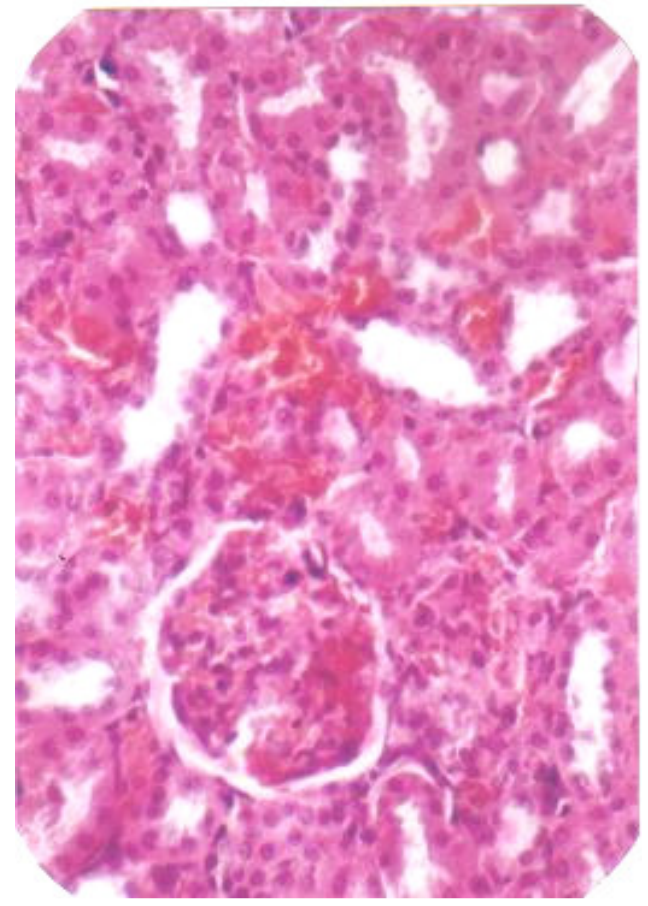

Fig (6): Section of the kidney of rat treated with ochratoxin and ginseng in combination for two weeks showing hemorrhage in the interstitial tissue (1).

(Hx \& Ex 200). 


\section{Protective effect of ginseng against toxic.....}

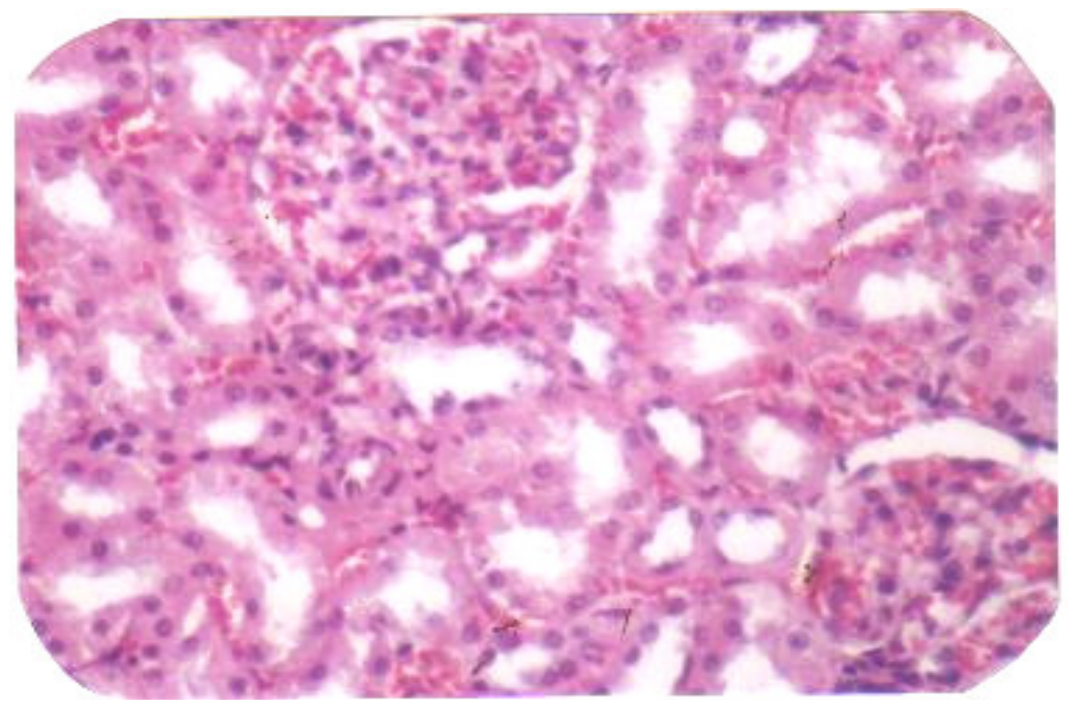

Fig (7): Section of the kidney of rat treated with ochratoxin and ginseng in combination for eight weeks showing hemorrhage in the interstitial tissue (1)and interglomerular hemorrhage (2).

(Hx \& Ex 200).

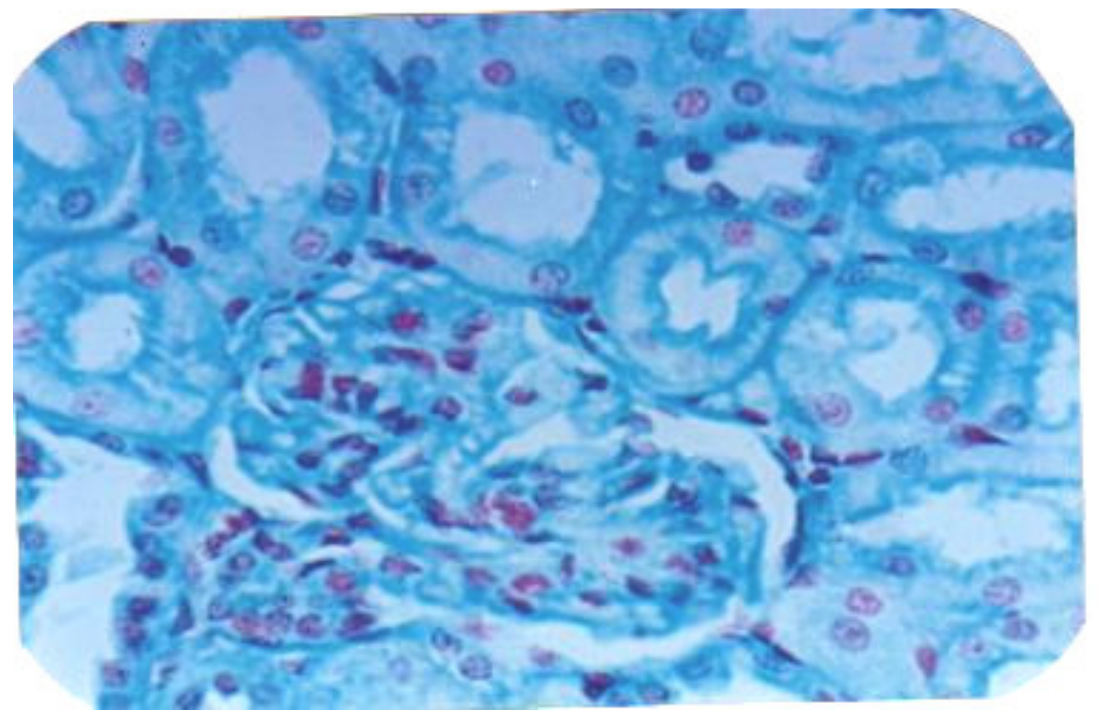

Fig (8): kidney section of control rat showing DNA content

(Feulgen reaction $\mathrm{x} 400$ ) 


\section{Fatma A. Morsy}

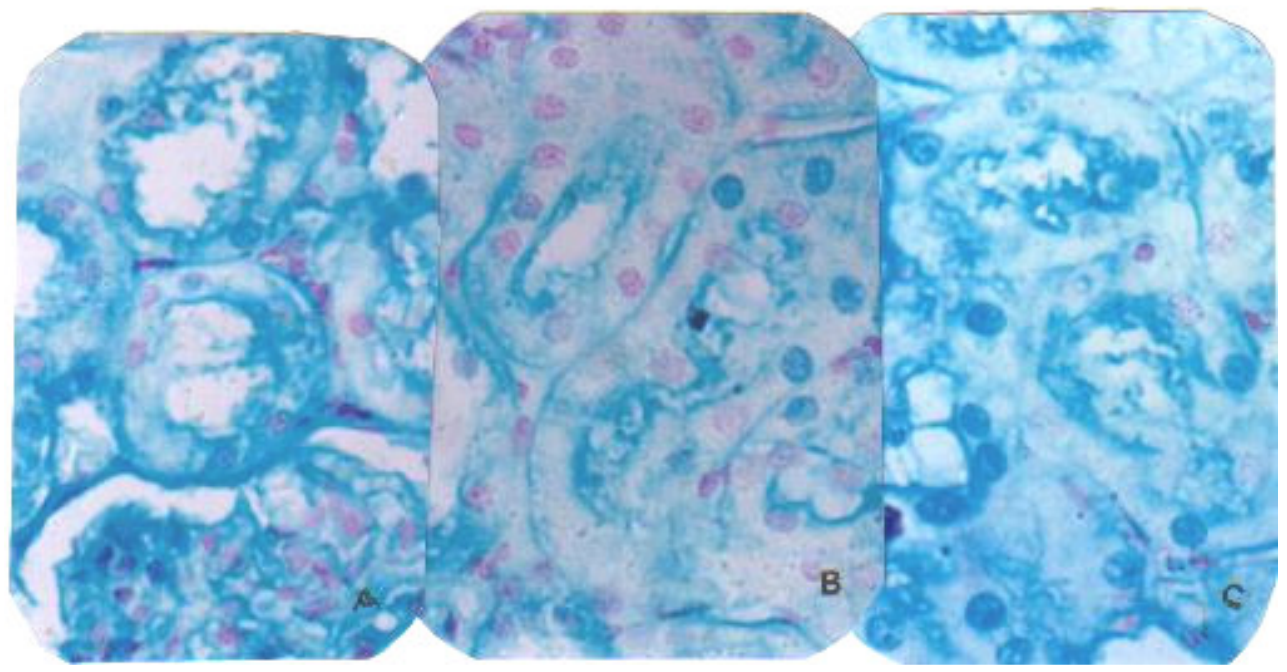

Fig (9):Section of the kidney of rat treated with OA for two weeks (A), four weeks (B) and eight weeks (C) showing decrease in DNA content (Feulgen reaction $\mathrm{x} 400)$.

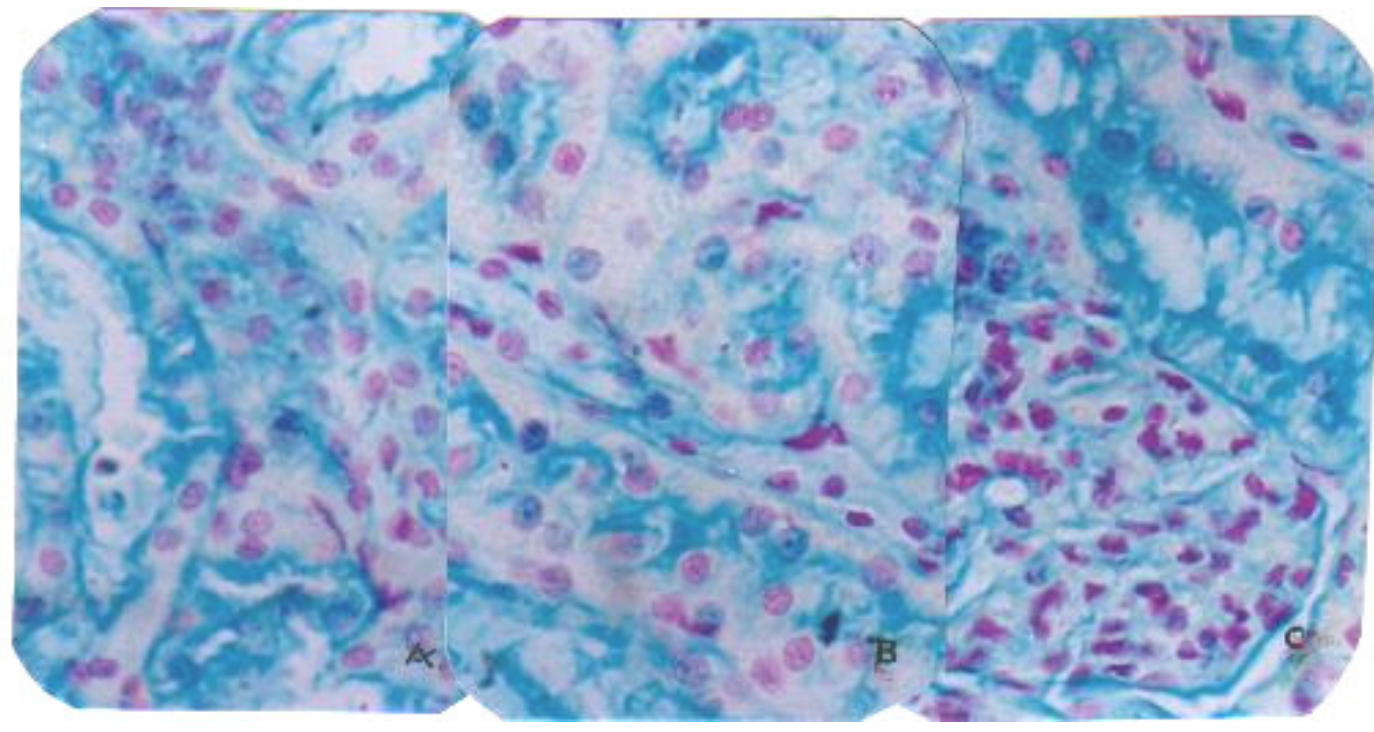

Fig (10): Section of the kidney of rat treated with ginseng and $\mathrm{OA}$ in combination for two weeks (A), four weeks (B) and eight weeks (C) showing an increase in DNA content in comparison to toxin alone.

(Feulgen reaction $\mathrm{x} 400$ ) 


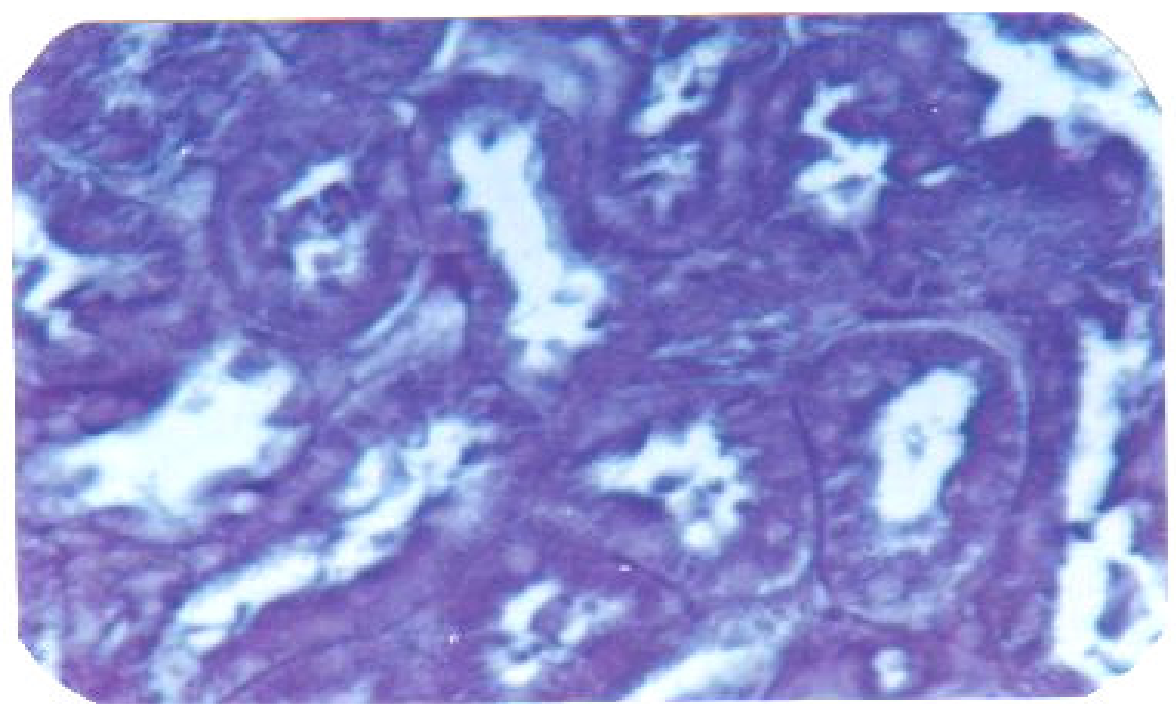

Fig (11): kidney section of control rat showing protein content in renal tubules

(Bromophenol bule stain $\mathrm{x} 400$ )

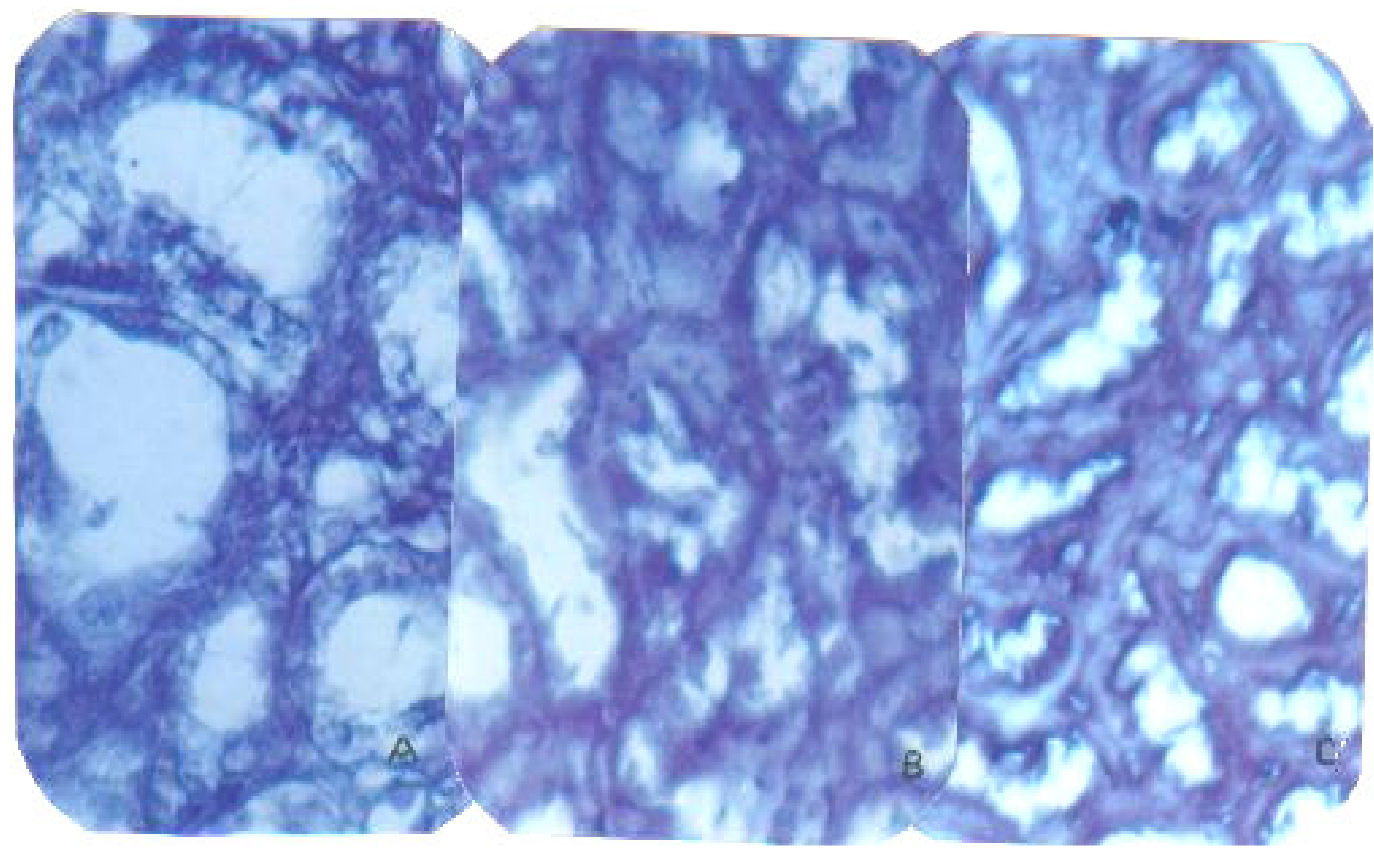

Fig (12): Section of the kidney of rat treated with OA for two weeks (A), four weeks (B) and eight weeks (C) showing a decrease in protein content (Bromophenol bule stain x 400) 


\section{Fatma A. Morsy}

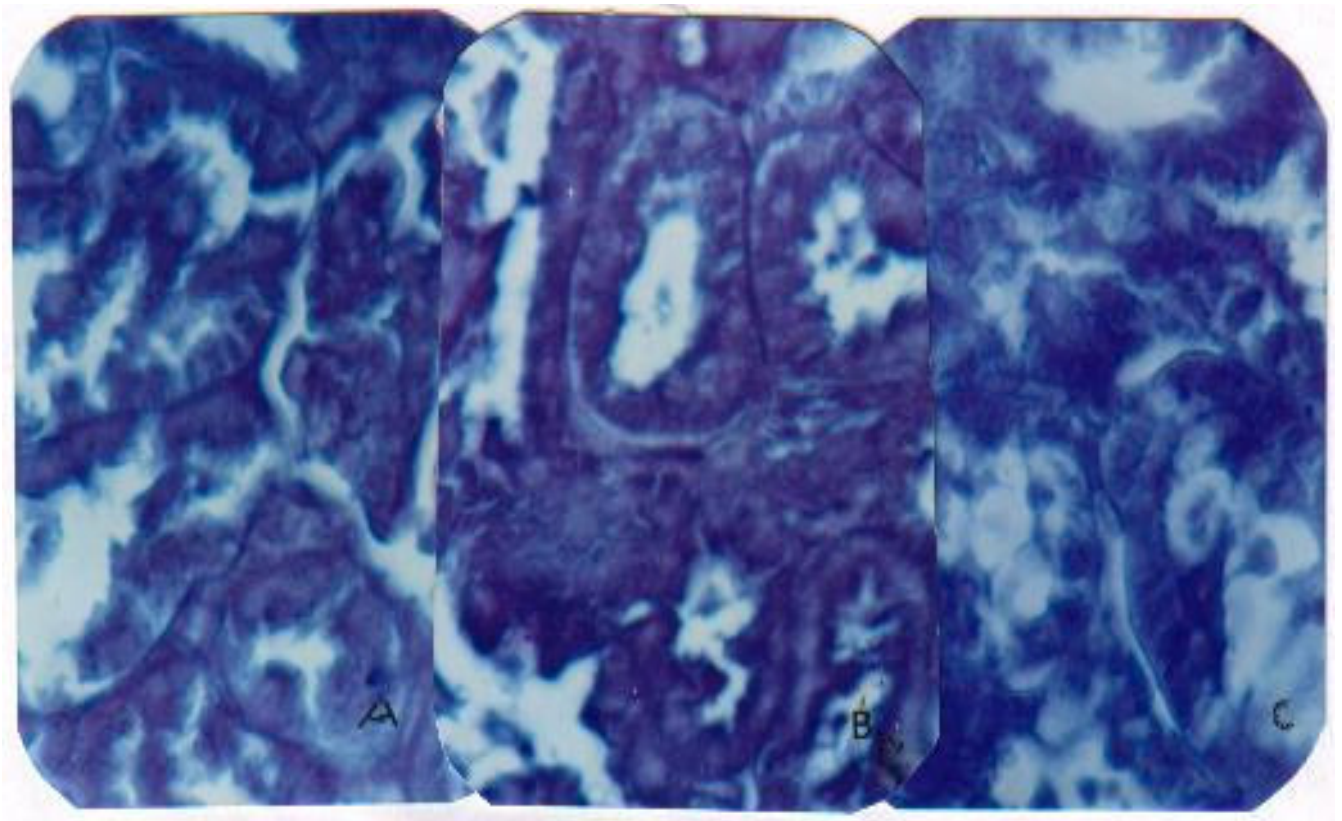

Fig (13): Section of the kidney of rat treated with ginseng and $\mathrm{OA}$ in combination for two weeks (A), four weeks (B) and eight weeks (C) showing an increase in protein content in comparison to toxin alone

(Bromophenol bule stain $\mathrm{x} 400$ )

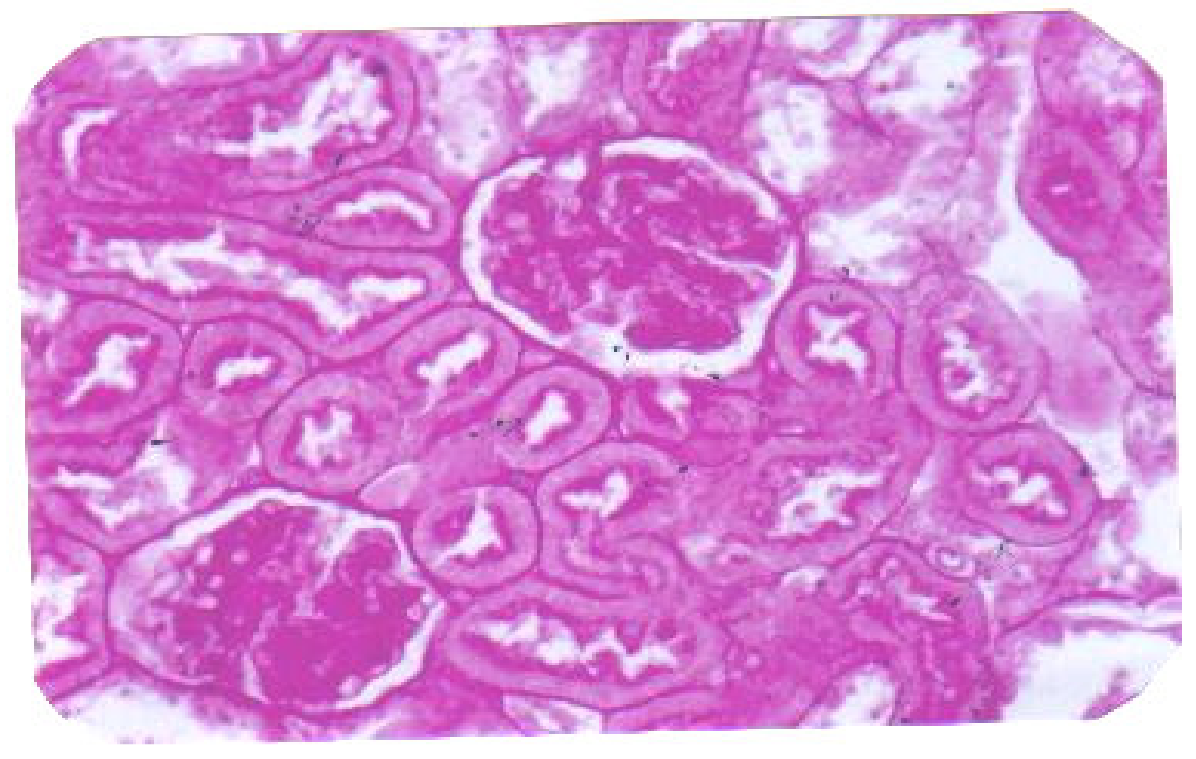

Fig (14): kidney section of control rat showing PAS+ve materials in the basement membrane and brush border of tubules

(PAS reaction $\mathrm{x} 200$ ) 


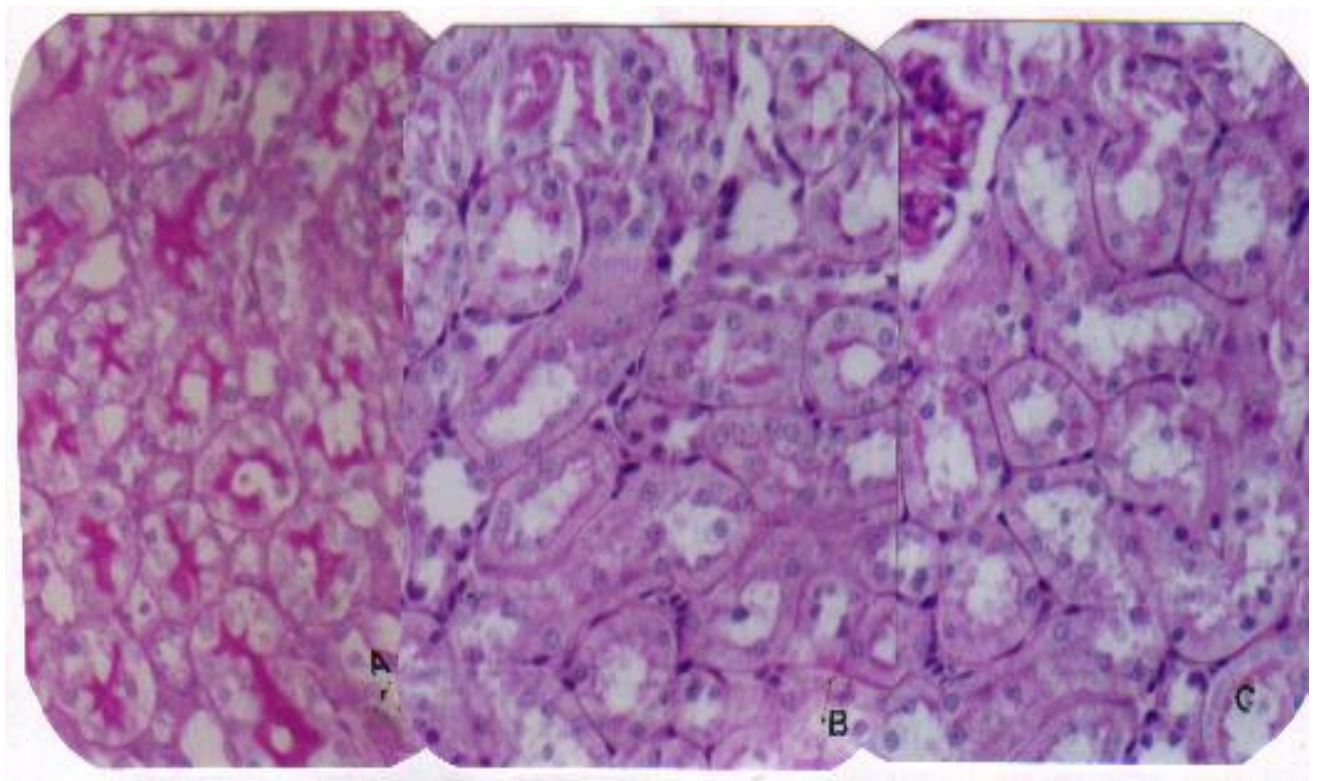

Fig (15): Section of the kidney of rat treated with OA for two weeks (A), four weeks (B) and eight weeks (C) showing a decrease in PAS +Ve materials (PAS reaction $\mathrm{x} 200$ )

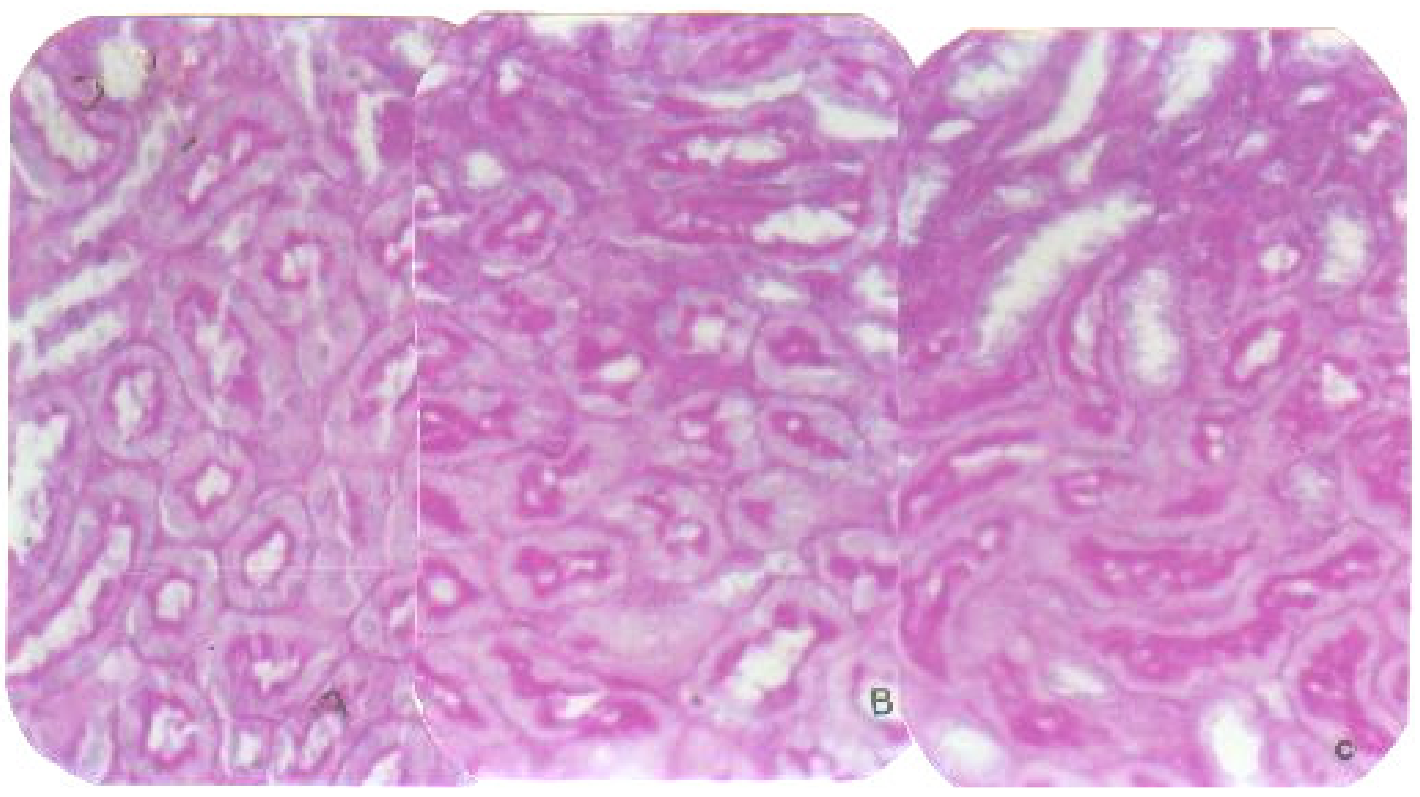

Fig (16): Section of the kidney of rat treated with ginseng and OA in combination for two weeks (A), four weeks (B) and eight weeks (C) showing an increase in PAS +ve materials in brush border of tubule.

(PAS reaction $\mathrm{x} 200$ ) 
Fatma A. Morsy

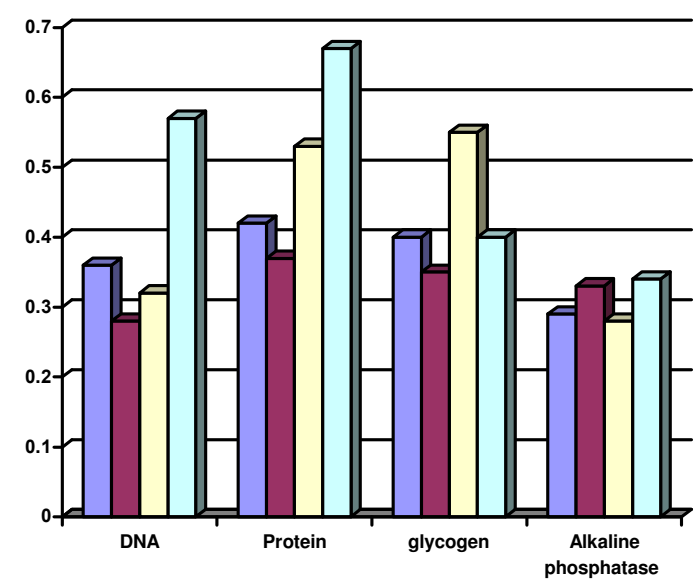

acontrol

$\square O A$

पOA+ Ginseng

aGinseng

2 weeks

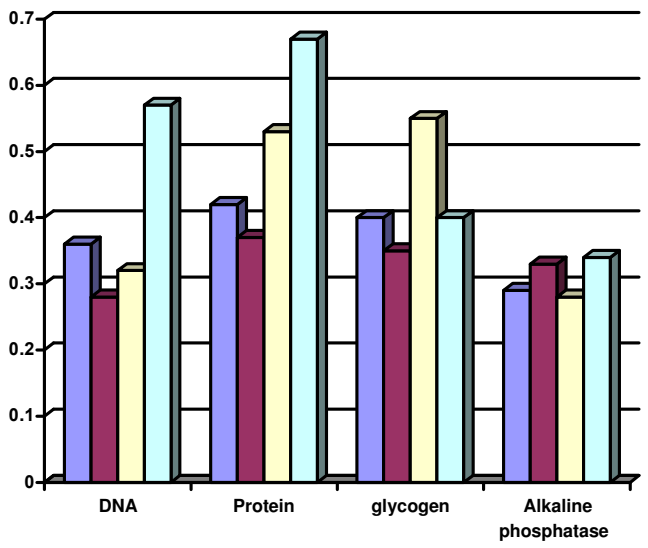

acontrol

$\square O A$

पOA+Ginseng

$\square$ Ginseng

4 weeks

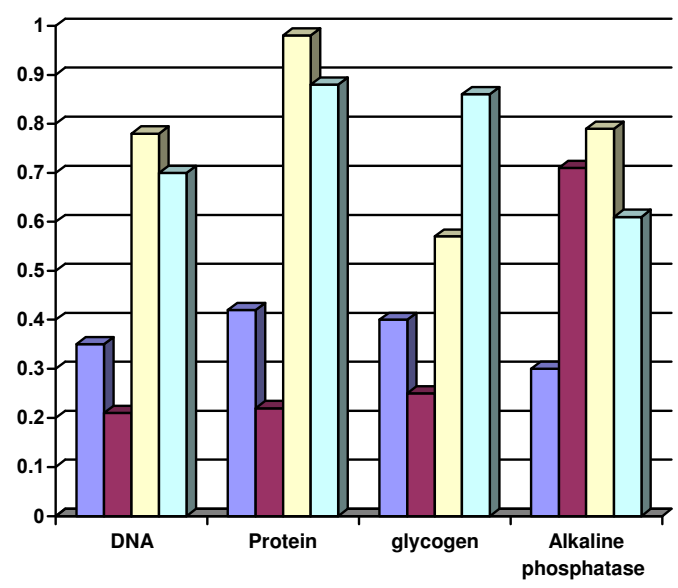

$\square$ control

$\square O A$

$\square O A+$ Ginseng

$\square$ Ginseng

8 weeks

Fig. (17): Optical density value of DNA, protein, glycogen content and alkaline phosphatase activity in kidney cells of male rats treated with ochratoxin A (OA) and or ginseng after two, four and eight weeks of intraperitoneal treatment. 


\section{References}

1.Abdel Wahhab, MA; Nada, S.A. and Arbid, M.S. (1999): Ochratoxicosis: prevention develop -pment toxicity by L. methionine in rats. Journal of Applied Toxicology vol. 19 issue 7-12.

2.Arlt, VM.; Pfohl-Leszkowicz, A.; Cosyns, J. and Schmeiser, H.H (2001): Analysis of DNA adducts formed by ochratoxin $A$ and aristolochic acid in patients with chinese herbs nephropathy. Mut Res Jul 25; 494 (1-2): 143-150.

3.Bashandy, S.A.; Nada, S.A.; Morsy, F.A. and Arbid, M.S. (1996): The role of ginseng on gonad ochratoxicosis $\mathrm{A}$ in rat. Union. Arab. Biol. Cairo. Vol. 5(A). Zoology, 227-250.

4.Baudrimant, I.; Sostaric, B. Yenot, C.; Betbeder, AM.; DanoDjedje, S.; Sanni , A.; Steyn, PS. And Creppy, EE. (2001): Aspartam prevents the karyomegally induced by ochratoxin $\mathrm{A}$ in rat kidneyArch Toxicol May; 75 (3) : 176183.

5.Biro, K.; Solti, L.; Barna-Vetro, I.; Bago, G.; Glavits, R.; Szabo, E and Fink Gremmels, J. (2002): Tissue distributin of ochratoxin as determined by HPLC and ELISA and histopathological effect in chicken. Avian pathol Apr; 31 (2): 141-148.

6.Bohm, J. (1992): The significance of the mycotoxins desoxynivalenol zearalenone a gricultrual domestic animals. Arch Tierenahr 42 (2): 95 111.

7.Bondy, GS and Pestak, JJ (2000): Immunomodulation by fungal toxins. J. Toxicol Environ Health Bcrit. Apr-Jun; 3 (2): 109-143.

8.Brien, E.D.; Heussener, A.H. and Dietrich, D.R. (2001): Speciessex- and cell type -specific effects of ochratoxin $\mathrm{A}$ and $\mathrm{B}$.
Toxicological sciences. 63, 256264.

9.Dorrenhaus, A.; Flieger, A.; Golka, K.; Schulze, A.; Albrecht, M.; Degen, GH and Follmann, W. (2000): Induction of unscheduled DNA synthesis in primary human urothelial cells by the mycotoxin ochratoxin A. Toxicol Sci. Feb., 53 (2): 271-277.

10. Duda, RB.; Zhong, Y.; Navas, V.; Michael, Z.; Toy, BR. and Alavarez, JG. (1999): American ginseng and breast cancer therapeutic agent synergistically inhibit MCF-7 breast cancer cell growth. Journal of surgical oncology Vol 72, (4) 230-239.

11. Durury, R.A.B. and Wallington, E.A. (1980): Carleton's histolo gical technique $4^{\text {th }}$ Ed oxford university press. Oxford, New York, Toronto.

12. Dwivedi, P. P. and Burns, R.B. (1984): Pathology of ochrato xicosis A in young broiler chick. Res. Vet. Sci., 36: 92-103.

13. Feulgen, R. and Rosenbeck, H.C. (1942): Manual Histological Demonstration Technique. Bullerwoth and Co. (Publishers) LTd. London.

14. Golinski, P. and Chelkwski, J. (1978): Spectral behavior of ochratoxin A in different solvents. J. Assoc. off. Anal. Chem., 61 (3): 586-589.

15. Gomori, G. (1951): Alkaline phosphatase of cell nuclei. J. Lab. Clin. Med., 37: 526-531.

16. Huff, W.E., Wyalt, R.D., Tucker, T.L. and Hamilton, P.B. (1974): Ochratoxicosis in the broiler chicken. Poultry. Sci., 53: 15851591.

17. Karber,G.(1941): Pharmakologish methoden Zur Aggundung Von. Arneimittin unde gifter und analyseih rer wirkungs weise vor. Med. Leopoled. Ther 
Wissenschaftiche Verlage Gerlage Gesse Schaft, M.B.H.

18. Kim, H.; Chen, X. and Gillis, C.N. (1992): Ginsenosides protect pulmonary vascular endothelium against free radical induced injury. Biochem. Biophys. Res. Commun., 189(2): 670-685.

19. Kim, SH.; Jeong, KS.; Ryuos, Y. and Kim, TH (1999): Panax ginseng prevents a poptosis in hair follicles and accelerates recovery of hair modullary cells in irradiated mice. In vivo. Mar-Apr; 12 (2) 219-222.

20. Kozaczynskiw， W (1994): Experimental Ochratoxicosis A in Chickens Histopahtological and histochemical study. Arch vet pol; 34 (3-4): 205-219.

21. Lebrum, S. and Fullmann, W. (2002): Detection of Ochratoxin A induced DNA damage in MDCK cells by alkaline single cell gell electrophoresis (comet assay). Arch Toxicol. Jan ; 75 (11-12): 734-741.

22. Lee, HC.; Hwang, SG.; Lee, YG.; Sohn, HO, Lee, DW.; Hwang, SY. and Moon, JY (2002): In vivo effects of panax ginseng extracts on the cytochrome P450-dependent monooxygenase system in the liver of 2, 3, 7, 8- tetrachlorodibenzo-pdioxin-exposed guine pig. Life Science. Jul 5; 71 (7) 957-769.

23. Mac-Manus, J.P.A. and Cason, J.E. (1950): Carbohydrate histoche -mistry studies by a cetylation technique. Periodic acid method. J. Exp. Med., 91: 651-668.

24. Marquadt, R.R. and Frohlich, A.A. (1992): A review of recent advances in understanding ochrat oxicosis. J. Anim. Sci., 70 : 39683988.

25. Mazia, D.; Bewer, P.A. and Alfert, M. (1953): The cytoche mical staining and measurement of protein with mercuric bromophenol blue. Biol. Bull., 104: 57-67.
26. Meki, A.R. and Hussein, A. (2001): Comparative Melatonin reduces oxidative stress induced by ochratoxin A in rat liver an kidney. Toxicology \& Pharmacology volum 130, Issue 3, November 305-313.

27. Monalova, Y.; Monalova, G.; Parvanova, L.; PetovaBocharova, I.; Gastegnaro, M. and Chernozemsky, IN (1991): Induction of characteristic chrom osomal aberrations particularly $\mathrm{x}$ trisomy in cultured human lymph ocytes. Mutat Res Aug.; 231 (2): 143-149.

28. Nishino, H.; Tokuda, H.; Masuda , M.; Satomi, Y.; Okada, Y. and Okuyama, T. (2001): Cancer chem.opreventation by ginseng in mous liver and other organ. J. Korean. Med Sci. Dec., 16 Supp: S 66-79.

29. Petkova- Bocharova, T.; Stoichev, II.; Chernozemsky, IN.; Castegnaro, Mand Phohleszkowicz, A. (1998): Formation of DNA adducts in tissues of mouse progeny through transplacental contamination and/or lactation after administration of a single dose of ochratoxin A to the pregnant mother. Environ. Mol Mutagen; 32 (2): 155-162.

30. Pfohl-Leszkowicz, A.; PetkovaBocharova, T.; Chernozemsky, IN and Castegnaro, M. (2002): Balkan endemic nephropathy and associated urinary tract tumours : a review on a etiological causes and potential role of mycotoxins: Food Add contam. Mar; 19(3): 282-302

31. Prior, M.G. (1976): Mycotoxin determination on animal feed stuffs and tissues in western Canada. Can. J. Comp. Med., 40: 73-79.

32. Rasonyi, T.; Schlatter, J. and Dietrich, DR (1999): The role of alpha $2 \mathrm{u}$-globulin in Ochratox-in A induced renal toxicity and tumors 
in F344 rats. Toxicol Lett. Jan 11; 104 (1-2): 83-92.

33. Sandhu, B.; Singh , H. and Singh, B. (1995): Pathological studies in broiler chicks fed a flatoxin or ochratoxin and inoculated with inclusion body hepatitis virus singly and in concurrence. Vet Res commun; 19 (1): 27-37.

34. Schwerdt, G.; Freudinger, R.; Silbernagl, S. and Gelke, M. (1999): Ocharatoxin A-binding protein in rat organs and plasma and in different cell lines of the kidney. Toxicology. Jul 1., 135 (1) 1-10.

35. Snedcor, G.W. and Cochran, W.C. (1980): Statistical Method. $7^{\text {th }}$ ed Iow state Univ. Press. Ames. Iowa USA.

36. Stoev, SD.; Daskalov, H.; Radic, B.; Domijan, AM and peraica, M. (2002): Spontaneous mycotoxin nephropathy in bulyarian chicken with unclarified mycotoxin a etiology. Vet. Res.; Jan -Feb. 33(1): 83-93.

37. Szczech, G.M.; Carlton, W.W. and Tuite, J. (1973): Ochratoxin A toxicosis in swin. Vet. Pathol., 10: 219-264.
38. Theron, J.J.; Vander Merwe, K.J.; Liebenberg, N.; Jouber, H.J.B. and Nel, W. (1966): Acute liver injury in ducklings and rats as a result of Ochratoxin poisoning. J. Pathol. Bacteriol., 91: 521-529.

39. Tran, QL.; Adnyana, IK.; Tesuka, Y.; Saiki, I.; Kurashigo, Y.; Tran, QK and Kadoto, S. (2002): Hepatoprotective effect Majonoside R2 the major saponin from Vietnamese ginseng (Panax Vietnamenesis) Plata-Med. May; 68 (5) 405-406.

40. Wang, JS and Groopman, JD (1999): DNA damage by ochratoxin A. Chem Biol Interact. Jun 15; 127 (1): 29-44.

41. Zanic-Grubisic, T.; Zrinski, R.; Cepelak, I., Petrik, J. and Radic, B. (2000): Studies of ochratoxin A induced inhibition of phenyl a lanine hydroxylase and its reversal by phenylalanine. Toxicol Appl Pharmacol Sep 1., 167 (2) : 132139.

42. Zhang, O.Y. (1992): Protective effects of ginsenosides on warm ischemic damage of the rabbit kidney. Ching-Hua-I-Hsueh- TsaChih-Taipei, 42 (2): 84-95. 


\title{
Fatma A. Morsy
}

\section{التأثير الوقائى لنبات الجينسنج ضد سمية الأوكراتو كسين في كلية الجرذان البيضاء}

\author{
فاطمة عدلى مرسى \\ قسم الباثولوجيا المركز القومى للبحوث
}

استهدفت هذه الدراسة تأثير نبات الجينسنج فن تقليل الآثار السامة للسم الفطرى الأوكراتو كسين وقد اســتخدم فن هذا البحث 62 من الجرذان البيضاء ووزعت الجرذان كالآتى:

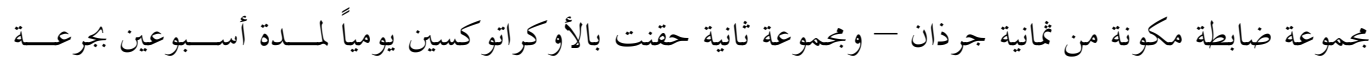

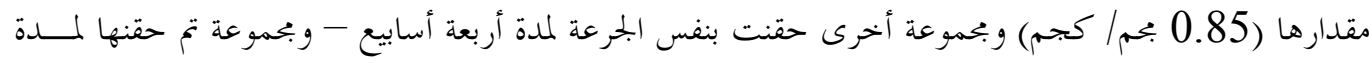
تمان أسابيع.

ثم تم حقن بحموعة أخرى من الجرذان بالمستخلص المائى لنبات الجينسنج (20بجم/كجم) قبل حقن الأوكراتو كسين

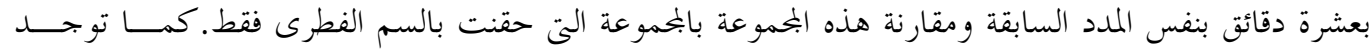
بحموعات أخرى حقنت بنفس المدد السابقة بالمستخلص المائى لنبات الجينسنج فقط.

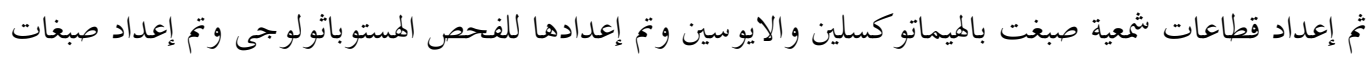

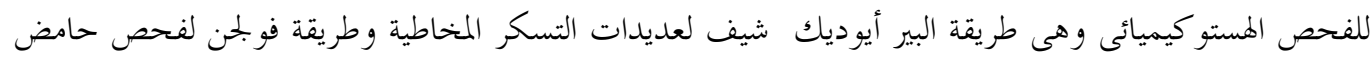

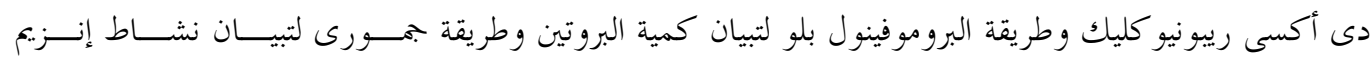

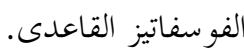

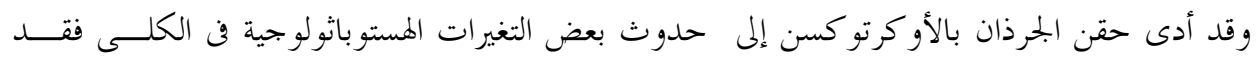

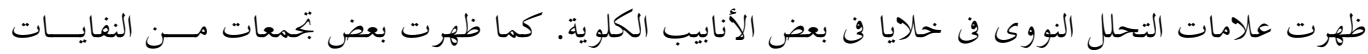
الخلوية والألياف الشفافة الهيالينية داخل تجويف بعض الأنابيب الكلوية.

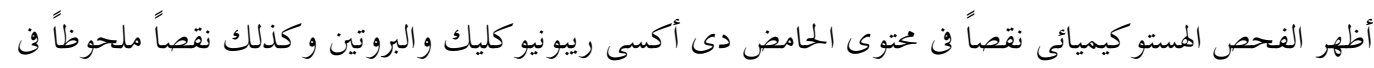

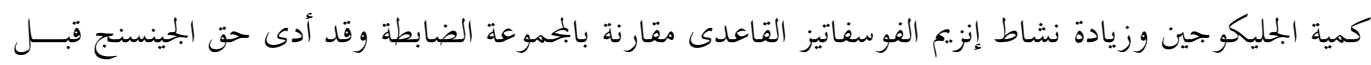
الأو كراتو كسين من تقليل نسبى للآثار السامة للأوكراتو كسين. 